\title{
Leger til folket
}

\author{
Ubesatte legestillinger, særlig i perifere strøk, har vært et kontinuerlig problem i norsk helsevesen helt frem \\ til de seneste årene. De siste 34 årene har helsemyndighetene gjennom forskjellige tiltak forsøkt å regulere \\ legemarkedet og fordele legestillingene. Opphør av kvotereguleringen i 2013 og myndighetenes målsetting \\ om nøye monitorering av legemarkedet reiser en rekke nye spørsmål.
}

Einar Skoglund

ei-skog@online.no

Siden 1974 har jeg arbeidet i Legeforeningen med spesialistutdanning av leger og med de sakene som har berørt dette området, blant annet utdanningskapasitet, fordeling av legestillinger og behov for leger/spesialister. I min jobb har jeg på nært hold kunnet følge helsemyndighetenes forskjellige utspill, forslag og tiltak samt Legeforeningens reaksjoner og forslag. Gjennom mange år har jeg observert forholdet mellom Legeforeningen og helsemyndighetene når myndighetene har tatt $\mathrm{i}$ bruk relativt drastiske tiltak. Jeg har også vært medlem av Nasjonalt råd for spesialistutdanning av leger og legefordeling i hele rådets eksistens 1999-2013. Med denne bakgrunnen vil jeg her kort redegjøre for de forskjellige reguleringsordningene for legefordeling og forsøke å vurdere hvilke virkninger de ulike tiltakene har hatt (fig 1).

\section{Etableringsloven 1979}

I 1970-årene var det dårlig legedekning i primærhelsetjenesten i enkelte områder på Vestlandet og i Nord-Norge, særlig i Finnmark. Utkantene og primærhelsetjenesten hadde tapt i ressurskonkurransen med de sentrale områdene og sykehusene. I Finnmark var det i 197838 primærleger og 39 leger i sykehus. I de tre nordligste fylkene sto 29 av 163 distriktslegestillinger ledige dette året. Det var bred enighet mellom alle parter om at nå måtte primærhelsetjenesten og utkantene prioriteres, men det var stor uenighet om tiltakene. Helsemyndighetene valgte den formelle løsningen, og i 1979 ble det vedtatt en midlertidig lov om adgang til å regulere legetjenester (1), også kalt etableringsloven. Ifølge loven skulle alle nye legestillinger godkjennes av et regjeringsoppnevnt råd. Ordningen omfattet også nye legepraksiser med rett til trygderefusjon. Loven skapte uenighet mellom legegrupper, og debattinnleggene i Tidsskriftet 1978-79 bærer preg av sterke synspunkter. Osloavisene hadde også store oppslag. Legefor- eningen var tydelig på, blant annet gjennom landsstyrevedtak, at loven ikke ville virke positivt på distriktshelsetjenesten dersom den ikke ble fulgt opp med betydelige stimuleringstiltak og tilføring av ressurser. Videre mente foreningen at lovvedtaket var hastverksarbeid og et billig politisk poeng som gjorde legene til syndebukker for mangeårige administrative og politiske forsømmelser overfor distriktshelsetjenesten.

Fra 1978 ble det innført fastlønnede distriktslegestillinger gjennom en avtale mellom staten og Legeforeningen (2). Disse stillingene ble først innført i Finnmark og Nord-Troms, og deretter videreført i distrikter i Nordland, Nord-Trøndelag, Møre og Romsdal og Sogn og Fjordane. Også til denne ordningen var det forskjellige holdninger i Legeforeningen. Ordningen syntes å ha en viss positiv effekt på rekrutteringen, antakelig fordi leger derved visste hva inntekten ble i en praksis i områder med lavt pasientgrunnlag. I tillegg fikk de rettigheter og positive ordninger som ansatte, blant annet fritid og mer ordnede arbeidsforhold. Da ordningen ble opphevet i 1984, var det bedre legedekning i primærhelsetjenesten i de nevnte områdene. I 1985 var det 134 yrkesaktive leger i Finnmark, hvorav 74 i kommunehelsetjenesten. Antall leger i kommunehelsetjenesten var altså nesten fordoblet i løpet av sju år. Den noe bedrede legedekningen samt et regjeringsskifte med Kåre Willoch som statsminister og med en mer liberalistisk ideologi, førte til at etableringsloven ble opphevet i 1983 (3).

\section{Beordringsloven 1988}

I 1988 fant myndighetene igjen at legedekningen i utkantstrøk var dårlig sammenliknet med utviklingen i mer sentrale områder, og det ble innført en midlertidig lov om stillingsstopp for leger (4). Det hadde nok også betydning at Gro Harlem Brundtland var tilbake i statsministerstolen. Denne loven ble kalt beordringsloven og inneholdt et generelt forbud mot å opprette nye stillinger i offentlig og privat virksomhet. Forbudet skulle vare i to år og gjelde fra 1. mars 1988. Loven ga Sosial- og helsedepartementet adgang til å forby nyansettelse i ledige stillinger.
Det var mulig å søke dispensasjon hos legefordelingsutvalget, som hadde sekretariat i Helsedirektoratet. Legeforeningen var enig $i$ at det var mangelfull legedekning $i$ utkantstrøk, men mente at dette måtte møtes med positive virkemidler og ikke med tvangsmessig regulering av legearbeidsmarkedet og inngrep i fri etablering og fritt legevalg. Legeforeningen markerte sin motstand med en fem timers streik, noe som resulterte i en motaksjon blant leger i Tromsø.

\section{Legefordelingsavtalen 1989}

Beordringsloven ble opphevet allerede 1. juli 1989 og avløst av avtale om tiltak for å bedre legedekningen i utkantstrøk, den såkalte legefordelingsavtalen. Avtalen ble inngått mellom Kommunenes Sentralforbund (KS), Oslo kommune og Den norske lægeforening 31. desember 1988, og ble senere tiltrådt av staten. Etter legefordelingsavtalen skulle det ikke opprettes nye legestillinger uten at det var innhentet tillatelse fra et partssammensatt legefordelingsutvalg (LFU) (5). Avtalen omfattet alle kommuner og i tillegg fylkeskommunale og statlige legestillinger, inklusive avtalehjemler for allmennpraktiserende leger og spesialister. Avtalen omfattet også stillinger innen private institusjoner som inngikk i fylkenes helseplaner.

\section{Stillingsstrukturavtalen 1985}

I 1985 inngikk staten, Kommunenes Sentralforbund, Oslo kommune og Den norske lægeforening enda en avtale, avtale om legers tilsetting i utdanningsstillinger, kalt stillingsstrukturavtalen (6). Formålet med avtalen var blant annet å sikre tilstrekkelig utdanningskapasitet og god kvalitet i spesialistutdanningen og å sikre en rimelig geografisk fordeling av legespesialister. Det ble samtidig ryddet opp i skjevheter som var oppstått i forholdet mellom antall underordnede og overordnede stillinger. Godkjente spesialister satt lenge i assistentog reservelegestillinger på den tiden, og en rekke underordnede stillinger ble omgjort til overlegestillinger. Avtalen førte til bedrede ansettelsesforhold for leger i spesialisering. Det ble innført faste stillinger ved 


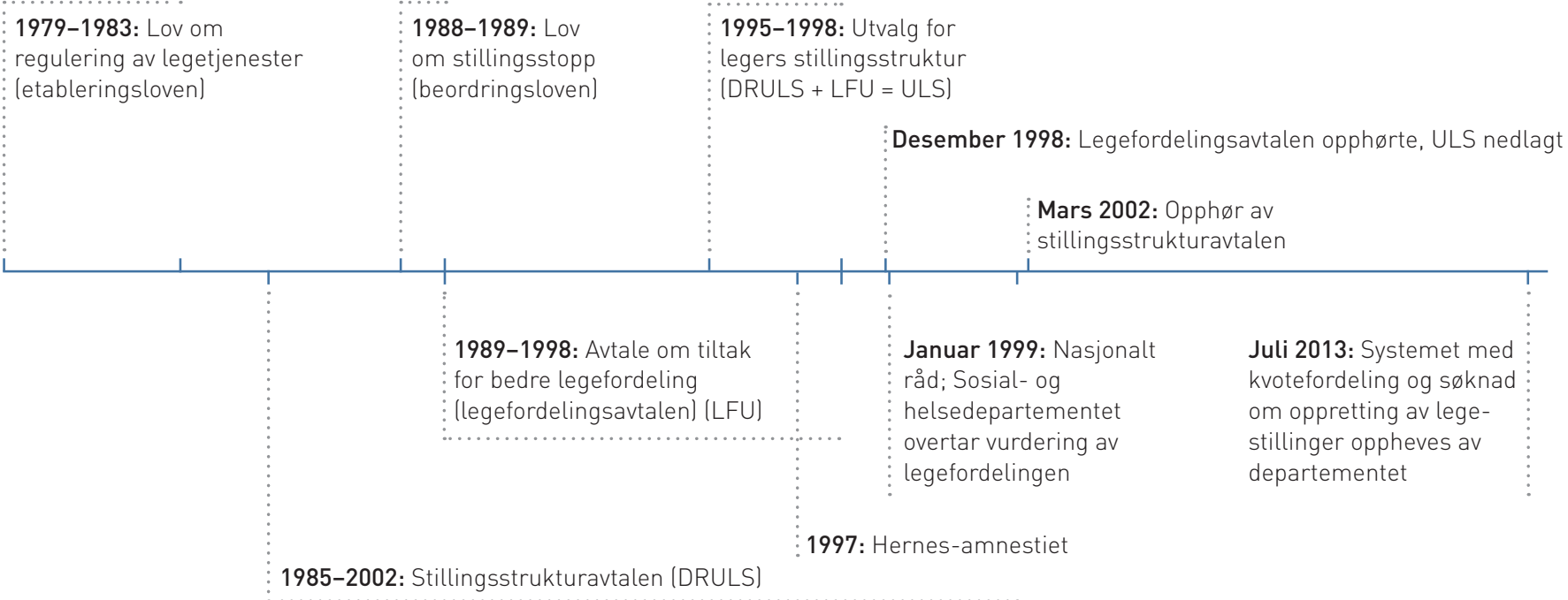

Figur 1 Reguleringsordninger som har virket inn på legestillinger og fordeling av disse

alle gruppe II-avdelinger fra Sogn og Fjordane og nordover, en ordning som var forutsatt å bli utvidet til hele landet. Dette ble imidlertid ikke fulgt opp. Avtalen ble forvaltet av et partssammensatt utvalg, det rådgivende utvalg for legers stillingsstruktur (DRULS) (7).

Ved reforhandling av legefordelingsavtalen og stillingsstrukturavtalen i 1995 ble de to partssammensatte utvalgene (LFU og DRULS) slått sammen til ett utvalg, kalt utvalg for legestillinger og stillingsstruktur (ULS) $(8,9)$.

Etter et par år fant det nye utvalgssekretariatet at sykehuseierne ikke hadde etterlevd avtaleverket og at det var opprettet flere stillinger enn det var gitt tillatelse til. Helseminister Gudmund Hernes ga sommeren 1997 et amnesti overfor de ulovlig opprettede stillingene. Man antar at ca. 1300 ulovlig opprettede legestillinger på denne måten ble gjort lovlige. Bakgrunnen for amnestiet var å rydde opp i stillingsstrukturen, men sannsynligvis oppfattet sykehuseierne det som et signal om at man kunne ta lett på avtaleverket, og sykehusene fortsatte å opprette nye legestillinger utover dem man fikk tillatelse til. Det ble stadig tydeligere for partene at avtalen ikke førte til den ønskede og avtalte reguleringen av legemarkedet. I desember 1997 sa derfor Kommunenes Sentralforbund og Oslo kommune opp både stillingsstrukturavtalen og legefordelingsavtalen med virkning fra 31. desember 1998.

Stillingsstrukturavtalen ble midlertidig forlenget ved at det ble inngått en overgangsavtale inntil 1. april 1999 mellom Kommunenes Sentralforbund, Oslo kommune, Legeforeningen og staten, som senere igjen ble forlenget ut 2001, deretter frem til mars 2002. Partene hadde tydeligvis ikke lenger tro på stillingsstrukturavtalen som et virkemiddel til å oppnå god spesialistutdanning og god legefordeling. Heller ikke helsemyndighetene la noe press på partene for å få videreført avtalen. Etter 2002 har det ikke eksistert noen avtaleregulering, men Helse- og omsorgsdepartementet meddelte $\mathrm{i}$ brev til de regionale helseforetakene at det var hensiktsmessig å legge den eksisterende fordelingen på faste og midlertidige utdanningsstillinger til grunn for videreføring av nyansettelser i utdanningsstillinger (10).

Etter hvert har stadig færre leger og administratorer kunnskap om avtalen som opphørte i 2002, og det har utviklet seg forskjellige kulturer for ansettelse og ansettelsestider ved sykehusene. Tendensen til stadig kortere ansettelsestider i utdanningsstillinger fører til uheldige forhold for gjennomføring av spesialiseringen, og behovet for en ny ryddig ordning for ansettelse av leger i spesialisering har vært der lenge. Det er beklagelig at et nytt system med fast ansettelse av leger i spesialisering i komplette utdanningsløp ennå ikke er etablert, selv om det ble politisk bestemt av helseminister Anne-Grete Strøm-Erichsen allerede i september 2010. Et moderne system med ansettelsesordninger mer i tråd med arbeidslivet for øvrig må til for å rydde opp i nåværende situasjon ved sykehusene og er nødvendig for å få til bedre strukturerte utdanningsløp.

\section{Nasjonalt råd - ny legeregulering}

Legefordelingsavtalen opphørte 31. desember 1998 og ble erstattet med en ny ordning under Sosial- og helsedirektoratet (11). I henhold til forskrift om spesialistutdan- ning av leger som trådte i kraft 1. januar 1999, opprettet Sosial- og helsedepartementet Nasjonalt råd for spesialistutdanning av leger og legefordeling (NR). Rådet ble sammensatt av representanter for staten, Statens helsetilsyn, Oslo kommune, helseregionene, universitetene, pasientforeninger og Legeforeningen. I tillegg til å være et rådgivende utvalg for Sosial- og helsedepartementet i overordnede spørsmål om spesialistutdanning av leger, skulle rådet gi anbefalinger om dimensjonering av de enkelte medisinske spesialiteter forut for departementets årlige fastsettelse av rammer for antall nye stillinger - både legestillinger/hjemler i kommunehelsetjenesten og legestillinger i spesialisthelsetjenesten. Dette var altså starten på departementets årlige kvotefordeling av nye legestillinger til hvert av de regionale helseforetak.

Etter helseforetaksreformen i 2002 har ordningen fungert slik at helseregionene og kommunene har meldt sitt behov for nye legestillinger inn til direktoratet/Nasjonalt råd for spesialistutdanning av leger og legefordeling. Rådet har gitt en anbefaling om totalt antall spesialiststillinger og stillinger for spesialisering i institusjonshelsetjenesten fordelt på hver region. Anbefalingen har gått til departementet, som så har tildelt et visst antall stillinger i sitt årlige oppdragsdokument til det enkelte regionale helseforetak. Det enkelte foretaket har deretter søkt det respektive regionale helseforetaket om tildeling av nye stillinger. Både i anbefalingen fra rådet og $i$ departementets oppdragsdokument til de regionale helseforetakene har det vært gitt signaler om spesialiteter som forutsettes prioritert.

Delegert fra departementet har rådets sekretariat tatt stilling til søknader om nye 
stillinger/hjemler i kommunehelsetjenesten. Kommunehelsetjenesten har hele tiden fått det antall nye hjemler det er bedt om.

I oktober 2003 fremmet rådet et forslag overfor Helse- og omsorgsdepartementet om ny stillingsstruktur for leger i sykehus. Det ble foreslått endrede ansettelsestider og en større andel faste stillinger for leger i spesialisering. Departementet har aldri besvart henvendelsen og har heller ikke besvart senere brev fra Legeforeningen der man minner om forslaget. Departementet har tydeligvis ikke villet involvere seg i dette forslaget, som opprinnelig hadde bakgrunn i en avtale mellom partene altså stillingsstrukturavtalen.

\section{0-årenes paradoks}

Samtidig som helsemyndighetene i 1980årene registrerte en legemangel og iverksatte tiltak for å få fordelt leger til utkantstrøk, fikk myndighetene mistanke om at det gikk mot et overskudd av leger. På tross av at Norge hadde kontinuerlig underskudd på leger og ubesatte stillinger, konkluderte et offentlig utvalg (Willumsen-utvalget) (12) i 1983 med at det ville bli legeoverskudd. Slutningene i helseplan for 1980-årene (13) var også kommende legeoverskudd. Bekymringen for et overskudd av leger hadde sammenheng med den generelle økonomiske situasjonen i landet, men den kommende økonomiske veksten ble undervurdert. Myndighetene besluttet å redusere opptaket på medisinstudiet fra 370 per år i 1980-82 til 300 per år i perioden 1984-87. Samtidig var det en reduksjon i antall medisinstudenter i utlandet. Tiltakene straffet seg i mange år etterpå i form av ytterligere legemangel og ubesatte stillinger.

\section{Avvikling av \\ kvotefordelingssystemet}

Helseminister Støre varslet i sin tale til sykehusene 30. januar 2013 at systemet med kvotefordeling av legestillinger til sykehusene skulle avvikles. I brev av 19. februar 2013 fra departementet ble det opplyst at legefordelingssystemet var utdatert, og at det ved etablering av foretaksmodellen var iverksatt nye og mer effektive styringssystemer. Det ble uttrykt at helseregionene hadde behov for større fleksibilitet i fordeling av legestillinger. Systemet med kvotefordeling og søknader om opprettelse av legestillinger ble opphevet med virkning fra 1. juli 2013.

Det er signalisert fra helsemyndighetene at legemarkedet og utdanningskapasiteten i spesialistutdanningen skal følges opp videre og analyseres blant annet ved hjelp av et bedre legestillingsregister, som også skal omfatte stillinger/hjemler i kommunehelsetjenesten.

\section{Oppsummering}

I dag er situasjonen og forutsetningene fullstendig endret siden regulering av legestillinger ble innført i 1979. Legedekningen er på et helt annet nivå, og det er ikke i samme grad en skjevfordeling av leger mellom landsdelene.

Ser man tilbake på de lovbaserte begrensningene i vekst $i$ antall legestillinger, hadde de sannsynligvis marginal effekt, men kanskje de til en viss grad bremset veksten i stillinger sentralt. Det er ganske åpenbart at den avtalebaserte kontrollen med opprettelse av nye legestillinger ikke fungerte. Det ble opprettet langt flere stillinger i sykehusene enn det legefordelingsutvalget og senere utvalg for legestillinger og stillingsstruktur ga anledning til i årene 1989-99. Kontrollen med å opprette legestillinger i sykehus hviler etter 2002 i stor grad på de regionale helseforetakene, og den strenge økonomistyringen i helseforetakene innebærer en kontroll på vekst i legestillingene på godt og vondt. De siste årene har det også vært tydelig at de regionale helseforetakene ikke har ønsket nye legestillinger i særlig grad. Det har vært tendenser til ledigholdelse av stillinger av økonomiske grunner, og tildelte kvoter er ikke nødvendigvis blitt benyttet.

Det er grunn til å anta at de forskjellige formene for regulering av legestillinger har ført til en bevissthet om behovet for en bedre fordeling av et knapphetsgode, og at de til en viss grad har bremset på utviklingen av antall legestillinger i sentrale områder. Likevel illustrerer Hernes-amnestiet at systemet ble forbigått ved opprettelse av ulovlige stillinger. Den sterkeste reguleringen har de siste årene sannsynligvis ligget i de regionale helseforetakenes økonomistyring og selvpålagte begrensning i opprettelse av nye stillinger. Samtidig har dette også gjort det vanskelig å få nye stillinger som det faglig og kvalitetsmessig har vært behov for i enkelte medisinske miljøer. Systemet har vært lite fleksibelt når man ut fra medisinske grunner har sett behov for flere stillinger ved en sykehusenhet.

De siste årene har det gjennom flere møter i Nasjonalt råd for spesialistutdanning av leger og legefordeling vært drøftet forslag om opphør av kvotefordelingssystemet. Helse-Nord var lenge skeptisk til opphør av ordningen, men etter hvert var alle de regionale helseforetakene enige $i$ at systemet ikke lenger var hensiktsmessig (14). Helsemyndighetene kan ved hjelp av helseforetakenes rapportering og en oppdatert stillingsdatabase ha oversikt og holde seg orientert om utvikling og status i legemarkedet. Departementet kan gjennom eierstyring og bestillerdokument pålegge de regionale helseforetakene endringer hvis det oppstår skjevheter. Konklusjonen ble derfor at det ikke lenger var hensiktsmessig med årlig kvotereguleringen av legestillingene.

\section{Hva vil skje nå?}

Spørsmålet er om fjerning av kvotereguleringen får den ønskede effekten. Nasjonalt råds database over legestillinger har hatt store svakheter. I geriatri er det for eksempel fastslått at antallet utdanningsstillinger som fremgår av databasen, ikke er i overensstemmelse med realitetene - den faktiske utdanningskapasiteten er fortsatt lav til tross for de mange politiske føringer. Det blir spennende å se om det nye legestillingsregisteret får bedre datakvalitet, og om funn i registeret omsettes i handling. Det er bebudet en nøye monitorering av legemarkedet som skal gjøre det mulig å følge opp eventuelle skjevheter. Vurdering av legedekningen bør skje i et større perspektiv enn kun ved oversikt over tilgang og avgang, aldersfordeling og utdanning av nye spesialister. Analysen må også ta hensyn til rask utvikling i medisinsk kunnskap, metodikk, teknologi og utstyr. Funksjonsfordeling, endring $i$ arbeidsoppgaver og omorganisering, endrede pasientstrømmer og demografisk utvikling må trekkes inn i vurderingen. Vil oppheving av kvotereguleringen føre til den ønskede fleksibiliteten i opprettelse og flytting av legestillinger ved dokumenterte faglige behov? Departementet har forutsatt at opprettelse av legestillinger fortsatt skal skje i tråd med de regionale helseforetakenes «sørge for»-ansvar, etter det helsepolitiske styringsbudskapet og innenfor de økonomiske rammene som er stilt til disposisjon. Vil avdelingsoverleger oppnå den etterlengtede fleksibiliteten til å ansette de leger som trengs innenfor en langsiktig planlegging av virksomheten? Eller vil økonomistyringen i helseforetakene fortsette å være like rigid, og derved sterkt styrende for legemarkedet?

\section{Einar Skoglund (f. 1946)}

er cand.mag. fra Historisk-filosofisk fakultet, Universitetet i Oslo. Han har arbeidet med legers videre- og etterutdanning i Den norske legeforening fra 1974 til han ble pensjonert i 2013.

Forfatter har fylt ut ICMJE-skjemaet og oppgir ingen interessekonflikter. 


\section{Litteratur}

1. Gedde-Dahl D. Midlertidig lov om adgang til regulering av legestillinger. Tidsskr Nor Lægeforen 1978; 98: 1345-9

2. Fastlønnsordning for distriktsleger i Nord-Norge. Tidsskr Nor Lægeforen 1978; 98: 345-8 og 811-3.

3. Skoglund E. Historikk om legefordeling. Tidsskr Nor Lægeforen 1999; 119: 287.

4. Lov om stillingsstopp: Sosialdepartementet med forskrifter. Tidsskr Nor Lægeforen 1988; 108: 2069-71.

5. Legefordelingsutvalget. I: Årbok for Den norske lægeforening 1990-1991. Oslo: Den norske lægeforening, 1991: 50 .

6. Ny stillingsstruktur-avtaleforhandlingene sluttført. Tidsskr Nor Lægeforen 1986; 106: 1161

7. Det rådgivende utvalg for legers stillingsstruktur. I: Årbok for Den norske lægeforening 1990-1991. Oslo: Den norske lægeforening, 1991: 50.

8. Skoglund E. Ny avtale om stillingsstruktur fra 1.9.1995. Tidsskr Nor Lægeforen 1995; 115 : 3667-9.

9. Utvalg for legestillinger og stillingsstruktur 1996. I: Årbok for Den norske lægeforening 1996-1997. Oslo: Den norske lægeforening, 1997: 50.

10. Brev av 7. mai 2002 fra Helsedepartementet til de regionale helseforetak. Ansettelser for leger i utdanningsstillinger.

11. Skoglund E. - Ny ordning for legefordeling. Tidsskr Nor Lægeforen 1999: 119: 287-8.

12. Willumsen E, Grund J, Kjelberg A et al. Utdanningskapasiteten for leger og fysioterapeuter. Utredning avgitt til sosialministeren, kultur- og vitenskapsministeren og finansministeren 12 . november 1982. Oslo: Sosial- og helsedepartementet, 1982

13. Grund J, Hjort PF, Lerche $C$ et al. Helseplan for 1980-årene. Oslo: Gyldendal, 1982.

14. Brev av 9. mars 2011 fra Helse SøR- $\emptyset \mathrm{ST}$ RHF til HOD. Konklusjoner etter møte 31. januar 2011 mellom de fire administrerende direktører i RHFene.

Mottatt 21. 5. 2013, første revisjon innsendt 3.6. 2013, godkjent 1.7. 2013. Medisinsk redaktør Hanne Støre Valeur. 